\title{
Exploration of Natural Dyes by Using a Combination of Caesalpinia sappan and Leucaena leucocephala L. Leaves.
}

\author{
Nita Kusumawati* \\ Chemistry Departement \\ Universitas Negeri Surabaya \\ Surabaya, Indonesia \\ nitakusumawati@unesa.ac.id
}

\author{
Anang Kistyanto \\ Economic Departement \\ Universitas Negeri Surabaya \\ Surabaya, Indonesia \\ anangkistyanto@unesa.ac.id
}

\author{
Samik \\ Chemistry Departement \\ Universitas Negeri Surabaya \\ Surabaya, Indonesia \\ samik@unesa.ac.id
}

\begin{abstract}
In this research an exploration of the potential use of Caesalpinia sappan and Leucaena leucocephala $L$. has been carried out as an alternative to environmentally friendly dyeing. To optimize the quality of the shades produced, pre-treatment is done using Turkish Red Oil (TRO) (washing) as well as alum and soda ash (mordanting). Both are applied to minimize the presence of contaminants and create intermediates for reactions between dyes and fabric fibers, while fixation is applied to suppress the reactivity of natural dye compounds to the surrounding environment. Thus, the color fastness can be improved. Natural dyeing uses $75 \%$ KKS/25\% DL; $50 \%$ $\mathrm{KKS} / \mathbf{5 0} \% \mathrm{DL}$; and $25 \% \mathrm{KKS} / 75 \%$ DL have produced shades of yellowish, brownish, reddish, purple and black with a color intensity in the range of $73.23 \%-89.08 \% ; 70.27 \%-84.32 \%$; and $\mathbf{7 9 . 7 3 \%} \mathbf{- 8 3 . 1 4} \%$ for fixation with iron(II)sulfate, alum and lime, respectively. Furthermore, the results of the staining scale analysis, dyeing with $75 \% \mathrm{KKS} / 25 \% \mathrm{DL} ; 50 \% \mathrm{KKS} / 50 \% \mathrm{DL}$; and $25 \% \mathrm{KKS} / 75 \%$ DL with fixation using iron(II)sulfate, alum and lime successively produce fastness on a scale of 3 (fair); 3-4 (good enough); and 3-4 (good enough).
\end{abstract}

Keywords-Textile, natural dyes, Caesalpiniasappan, Leucaena leucocephala, brazillin, tannin

\section{INTRODUCTION}

Three basic ingredients that cannot be released from human life are clothing, food, and shelter. Clothing is one of the basic needs that is experiencing rapid development in seconds every day. Clothing is experiencing rapid development in terms of models and colors used. The dyes used are mostly synthetic dyes. Synthetic dyes have their own charm in the world of textiles because they have several advantages. These advantages include a more affordable price, a stronger and more stable color, a more practical use, and an easily available presence. However, the use of these dyes has a large number of negative impacts on the environment and health [1-3].

Synthetic dyes contain a number of pollutants including heavy metals that are very dangerous for the environment and health. A number of heavy metals that accompany the presence of synthetic dyes in textile wastewater include $\mathrm{Cu}$,
$\mathrm{Ni}, \mathrm{Cr}, \mathrm{Hg}$, and Co. These heavy metal pollutants generally come from the mordanting stage in dyeing. The intensive production of textiles will trigger the entry of large quantities of mutagenic dyes and heavy metals into the aquatic environment and pollute all life in them, including water sources for human life. Some countries such as the Netherlands and Germany have banned the use of this dye [4]. This condition is the background of the need for environmentally friendly alternative dyes, namely natural dyes [5-6]. Natural dyes can be obtained from various components of biological resources, such as root and wood bark, flowers, and leaves of some plants [7-11].

Utilization of a number of natural dyeing sources such as tarum (Indigofera tinctoria) leaf, areca nut (Areca catechu), turmeric (Curcuma longa L.), mangosteen rind (Garcinia mangostana), kesumba (Bixa orellana), mahogany root (Morinda citrifolia), brazilwood bark (Caesalpinia sappan), tinggi bark (Ceriops candolleana Arn), ketapang (Terminalia catappa) leaf, teak leaf (Tectona grandis), and lamtoro (Leucaena leucocephala L.) leaf[12-14] Color instability has become a problem for practitioners and researchers in textile technology, and standardization of procedures is needed to overcome this problem.

Brazilwood (Caesalpinia sappan) is a type of plant that has been known as the main ingredient of herbal medicine [15]. Brazilwood has yellow flowers with yellowish green fruit and oval-shaped. The substances contained in brazilwood include gallic acid, brazilin, delta- $\alpha$-phellandrene, oscimene, resorcinin, essential oils, and tannins [16]. Meanwhile, brazilwood leaves contain essential oils up to $0.20 \%$, colorless and odorless. The bark and root of the barzilwood produce a deep red color, which is produced by the brazilin compound. Besides having dyeing ability, this compound also has antioxidant and antimicrobial properties. The deep red color will appear when the bark and root of the brazilwood are dissolved in a suitable solvent. Solvents that can be used include water, ethanol and methanol. Apart from brazilwood, lamtoro also has body parts that can be used as natural dyeing agents. 
Lamtoro (Leucaena leucocephala L.), also known as Chinese petai, is a tree that is generally used as a greening media and to prevent soil erosion. Lamtoro can grow to as high as 5-15 $\mathrm{m}$ with 4-8 pairs of double pinnate leaves. Lamtoro tree trunks are brown with flat fruit. Lamtoro contains several substances including alkaloids, saponins, flavonoids, mimosin, leukanin, and tannins. Lamtoro leaves produce a yellowish green color that comes from the tannin compounds in it [17]. This color will appear if the lamtoro leaves are dissolved in polar solvents such as water, ethanol, and methanol

\section{MATERIAL AND METHODS}

\section{A. Material}

A number of main materials used for the preparation and use of natural dyes include the brazilwood bark and lamtoro leaf material, each obtained from UD Sinar Agung and the environment around Universitas Negeri Surabaya. Other ingredients used are: (1) Turkish Red Oil (TRO, 70\%) derived from CV. Dunia Kimia (Surabaya, Indonesia), (2) mordanting agent including alum $\left(\mathrm{Al}_{2}\left(\mathrm{SO}_{4}\right)_{3}, \geq 17 \%\right)$ and soda ash $\left(\mathrm{Na}_{2} \mathrm{CO}_{3}, \geq 48 \%\right.$ ), each obtained from PT. Brataco and $\mathrm{CV}$. Water (Surabaya, Indonesia); (3) fixers, including iron (II) sulfate $\left(\mathrm{FeSO}_{4} .7 \mathrm{H}_{2} \mathrm{O}, \mathrm{d} 2.84 \mathrm{~g} / \mathrm{cm}^{3}\right)$ and calcium oxide $\left(\mathrm{CaCO}_{3}, \geq 90 \%\right)$, each obtained from PT. Nusa Indah Megah and Mitra Water (Surabaya, Indonesia). Especially for alum fixer, the specifications of the material used are the same as those used in the mordanting stage.

\section{B. Mordanting}

Mordanting is needed to improve the reaction of dyes with textile fibers, so that a stable color can be produced on the fiber. Mordanting is done through the preparation of $25 \mathrm{~cm} \times 25 \mathrm{~cm}$ fabric fibers. To optimize the mordant that can be attached to the fiber, immersing the fabric in $34.2 \mathrm{~mL}$ of $2 \mathrm{~g} / \mathrm{L}$ TRO solution for $6 \mathrm{~h}$. To ensure the fabric fibers are free of residues, the fabric fibers are rinsed three times, each using $34.2 \mathrm{~mL}$ of water. The fabric fibers are then dried in the open air and ready for use in order. Mordant solution was prepared by dissolving 34.2 grams of alum and 2.74 grams of soda ash in $0.68 \mathrm{~mL}$ of water. Mordant solution is stirred for $5 \mathrm{~min}$ using a magnetic stirrer, to ensure homogeneity of the solution. The mordant solution is then heated to $100{ }^{\circ} \mathrm{C}$, and fabric fibers are inserted into it for $1 \mathrm{~h}$ while continuing to heat. Immersing in a mordant solution is continued for $24 \mathrm{~h}$. To get a mordant residue-free fabric, rinse three times, each using $34.2 \mathrm{~mL}$ of water and then dried. The fiber fiber is then ironed to get a uniform fiber orientation and is ready to be dyed.

\section{Natural Dyeing}

The preparation of natural dyeing extracts from the brazilwood bark and lamtoro leaves is done through the preparation of $500 \mathrm{~g}$ of raw material that has been blended. Subtle ingredients are then extracted using a water solvent with a material/solvent ratio of 1:10, while being heated. The extraction process with heating is carried out until the volume of the solution is half from the beginning. The dye extract is filtered using two layers of fabric, to get a clear extract. The natural dyeing extract is cooled and ready to be used in dyeing. Fabric dyeing is done by immersing $7 \mathrm{~g}$ of fabric fiber measuring $25 \times 25 \mathrm{~cm}$ using $36 \mathrm{~mL}$ extracts of natural dyes. The dyeing is carried out through 10 dips, each for $5 \mathrm{~min}$, with pauses between immersions for $1 \mathrm{~min}$. To reduce the reactivity of the dye with the surrounding environmental components, fixation is carried out.

\section{Fixation}

Color locking or fixation is done in order to increase color fastness. The fixer solution was prepared by dissolving 50 grams (iron(II)sulfate, alum, and lime) in $1 \mathrm{~L}$ of water. The solution is allowed to stand for $24 \mathrm{~h}$ to get the transparent part. For the fixation process, a fabric fiber is immersed in the fixer solution for $10 \mathrm{~min}$, and dried.

\section{E. Analysis}

The quality of colors produced by natural dyes on cotton fibers was evaluated by a number of analyzes: (a) color intensity using Shimadzu Ultra Violet Diffuse Reflection (DRUV) UV-2401-PC Spectrophotometer; and (b) color fastness using the Gray Staining Scale method

\section{RESULT AND DISCUSSIONS}

\section{A. Dyes Preparation}

In this study, dyeing was carried out using a combination of two or more dyes, known as hybrid dyeing. The application of this method is done to enrich the color shades that can be produced by natural dyes. This relates to the presence of natural dyes which so far have been limited to the brownish and blackish shades characteristic of bark material, which tend to be boring. In addition, the hybrid dyeing method can be a solution for the absence of seasonal raw materials, through the provision of the same color shades. Thus, the sustainability of raw materials is no longer a barrier to natural dyeing. A hybrid dyeing method was applied in this study involving brazilwood bark and lamtoro leaf material.

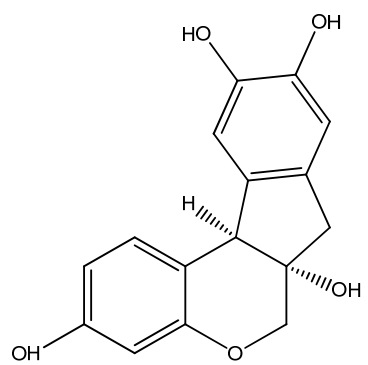

Figure 1Brazillin molecular structure

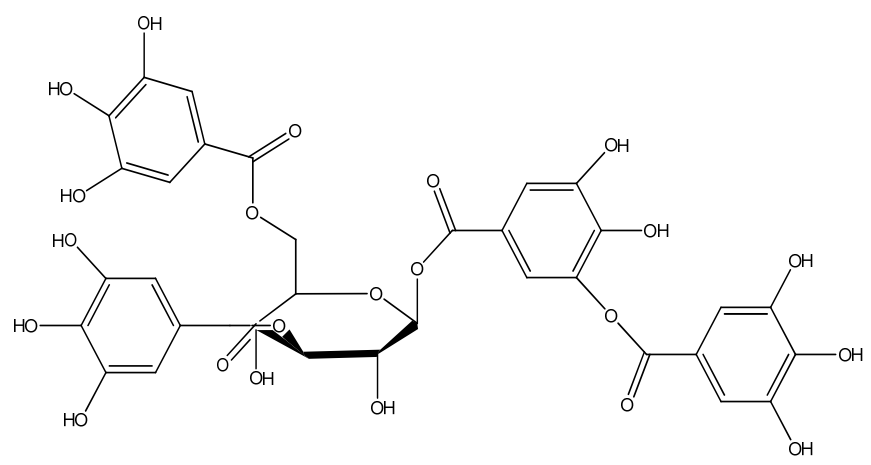

Figure 2 Tannin molecular structure 
To optimize dyeing, the fabric fibers go through a pretreatment stage. Preparations include washing using TRO and mordanting using alum and soda ash. Washing will eliminate contamination, both by polar and non-polar compounds, which inhibits the entry of mordanting agents. Like other surfactants, TRO has both polar and non-polar functional groups in its molecular structure. The existence of these polar functional groups will trigger the solubility of water-based contaminants, while non-polar functional groups will induce solubility of fat-based contaminants. The minimum contaminants in fabric fibers will open the broadest way for reactions with mordanting agents, which in this case act as intermediates for the reaction between fabric fibers and natural dyes which tend to have the same charge. Thus, the color intensity can be increased.

Mordanting is a part of fabric pre-treatment which also determines the success rate of dyeing. Mordanting determines the stability of the reaction between the dye and fabric fibers. Besides being closely related to color stability, the success of mordanting will also determine the distribution and sharpness of the resulting color. Metal mordant is one type of mordant that has been used extensively in textile natural dyeing. Alum and soda ash are two of the few types of mordant compounds. In dyeing, alum and soda ash act as an intermediary for the reaction between fabric fibers and natural dyes that have the same charge tendency, which is negative. The same charge tendency causes the minimum reaction that occurs between fabric fibers and natural dyes. This condition triggers a low intensity of colors. As a solution to this problem, the existence of a positively charged mordant with a valence of more than one, as an intermediary reaction between the two is very necessary. The bonds formed between fibers, mordant, and natural dyes will play an important role in determining the change in color intensity in the fabric caused by washing, sunlight, heat from ironing and also sweat.

In dyeing, the type of chromophore and auxochrome that accompany will be the determinant of the color shades that appear. In Fig. 1 you can see brazillin compounds contained in the brazilwoodbark material, which will trigger the appearance of strong red shades on cotton fibers. Specifically, the brazilin compound specifically has the $\mathrm{C}=\mathrm{C}$ chromophore group accompanied by auxochromes $\mathrm{C}-\mathrm{O}$ and $-\mathrm{OH}$ which are responsible for the appearance of this color shades. Meanwhile, tannin compounds have more varied chromophore and auxochrome groups, through the presence of $\mathrm{C}=\mathrm{C}$ and $\mathrm{C}=\mathrm{O}$ as chromophores and $\mathrm{C}-\mathrm{O}$ and $-\mathrm{OH}$ as auxochromes. Specifically for tannin dyeing, the resulting color shade will be determined by tannin classification, where the presence of hydrolyzed tannins and condensed tannins is responsible for the appearance of bright colors to dark red, brownish and even blackish.

The application of a hybrid dyeing method that combines brazillin in brazilwood bark and tannin in lamtoro leaves has produced a more varied color shade. Dyeing using lamtoro leaf extract gives a touch of yellowish green color derived from tannin compounds in it, while dyeing using lamtoro leaf provides a brighter and softer color effect compared to dyes from brazilwood bark.

After pre-treatment and dyeing, fixation becomes the final step that serves to improve the color fastness that has been produced. Fixation is done to lock the dye that has reacted with the fabric. Besides being able to lock colors, fixers are also able to induce color differences, before and after fixation.
TABLE I. HIBRID DYEING RESULTS WITH A COMBINATION OF BRAZIL WOOD BARK AND LAMTOROLEAF MATERIAL

\begin{tabular}{|c|c|c|c|}
\hline No. & $\begin{array}{c}\text { Material } \\
\text { Composition } \\
(\% \mathrm{v} / \mathrm{v})\end{array}$ & Fixer & Color Shade \\
\hline \multirow{3}{*}{1} & \multirow{3}{*}{ KKS (100) } & $\begin{array}{c}\text { Iron (II) } \\
\text { sulfate }\end{array}$ & \\
\hline & & Alum & \\
\hline & & Lime & \\
\hline \multirow{3}{*}{2} & \multirow{3}{*}{$\begin{array}{c}\mathrm{KKS} / \mathrm{DL} \\
(75 / 25)\end{array}$} & $\begin{array}{c}\text { Iron (II) } \\
\text { sulfate }\end{array}$ & \\
\hline & & Alum & \\
\hline & & Lime & \\
\hline \multirow{3}{*}{3} & \multirow{3}{*}{$\begin{array}{c}\text { KKS/DL } \\
(50 / 50)\end{array}$} & $\begin{array}{c}\text { Iron (II) } \\
\text { sulfate }\end{array}$ & \\
\hline & & Alum & \\
\hline & & Lime & \\
\hline \multirow{3}{*}{4} & \multirow{3}{*}{$\begin{array}{c}\mathrm{KKS} / \mathrm{DL} \\
(25 / 75)\end{array}$} & $\begin{array}{c}\text { Iron (II) } \\
\text { sulfate }\end{array}$ & \\
\hline & & Alum & \\
\hline & & Lime & \\
\hline \multirow{3}{*}{5} & \multirow{3}{*}{ DL (100) } & $\begin{array}{c}\text { Iron (II) } \\
\text { sulfate }\end{array}$ & \\
\hline & & Alum & \\
\hline & & Lime & \\
\hline
\end{tabular}

The color changes that occur depend on the chromophore and auxochrome groups in the molecular structure of each fixer. Utilization of iron (II) sulfate as a fixer tends to produce fiber colors that are darker than the extract color. Meanwhile, the 
use of alum and lime, each producing a fabric color that is similar to the original color and the color is brighter than the original color. Table 1 shows the color shades produced after fixation using the three fixer compounds.

\section{B. Analysis}

The intensity of the colors produced by each of the dyeing operational conditions can be seen in Table 2. The resulting color intensities are derived from brazilin in brazilwood bark and tannin on lamtoro leaves, as well as a mixture of both. Brazillin dyeing with the highest intensity (89.36\%) was produced from alum fixation, while the highest intensity $(87.60 \%)$ in tannin dyeing was obtained from fixation using iron (II) sulfate. Hybrid dyeing that combines dyeing with brazilin and tannin produces the highest color intensity $(89.08 \%)$ resulting from dyeing with a composition of $75 \%$ $\mathrm{KKS} / 25 \% \mathrm{DL}$ and fixation using iron(II)sulfate. In general, the presence of tannins in hybrid dyes tends to reduce the color intensity of the results of alum and lime fixation. Contrary to this result, in hybrid dyeing and fixation using iron(II)sulfate tends to increase the intensity of the resulting color. These results indicate a more effective reaction between a combination of brazillin and tannins with an iron(II)sulfate fixer. The large size of the alum molecule minimizes the reactions that occur with fiber due to the effect of space tightness. Meanwhile, although not as significant as the decrease in intensity resulting from alum fixation, positive charges with lower valence in the lime fixer have caused suboptimal reactions formed by fixers with natural dyes on the fiber.

TABLE II. COLOR INTENSITY WITH VARIOUS COMPOSITIONS OF HYBRID NATURAL DYES AND FIXERS

\begin{tabular}{|c|c|c|c|}
\hline No. & $\begin{array}{l}\text { Dyes } \\
\text { Composition } \\
(\% \mathrm{v} / \mathrm{v})\end{array}$ & Fixer & $\begin{array}{l}\text { Color } \\
\text { Intensity } \\
(\%)\end{array}$ \\
\hline 1 & KKS (100) & Iron (II) sulfate & 80.94 \\
\hline 2 & KKS (100) & Alum & 89.36 \\
\hline 3 & KKS (100) & Lime & 82.54 \\
\hline 4 & KKS/DL (75/25) & Iron (II) sulfate & 89.08 \\
\hline 5 & KKS/DL $(75 / 25)$ & Alum & 73.23 \\
\hline 6 & KKS/DL (75/25) & Lime & 74.27 \\
\hline 7 & KKS/DL (50/50) & Iron (II) sulfate & 84.32 \\
\hline 8 & KKS/DL (50/50) & Alum & 70.27 \\
\hline 9 & KKS/DL (50/50) & Lime & 75.14 \\
\hline 10 & KKS/DL (25/75) & Iron (II) sulfate & 80.58 \\
\hline 11 & KKS/DL (25/75) & Alum & 79.73 \\
\hline 12 & KKS/DL (25/75) & Lime & 83.14 \\
\hline 13 & DL (100) & Iron (II) sulfate & 87.6 \\
\hline 14 & DL (100) & Alum & 30.89 \\
\hline 15 & DL (100) & Lime & 80.44 \\
\hline
\end{tabular}

Table 3 shows the color fastness that results from hybrid dyeing of brazillin and tannin. The fastness scale indicates that hybrid dyeing with iron(II)sulfate fixation has higher fastness compared to alum and lime. The size of the iron (II) sulfate molecule that is between alum and lime is the advantage of this fixer. Molecular size not as large as alum has allowed more iron(II)sulfate molecules to enter and react with natural dyes on the fiber. The more intensive barrier created by this fixer will prevent the re-hydrolysis of the dye in the fiber and the high reactivity of the dye with the surrounding environmental components. Thus, the color intensity and fastness can be maintained or even increased. However, when viewed in terms of the resulting color shade, the use of alum fixers is able to produce the red color visualization closest to the color of brazilwood bark extract. Much darker colors are produced by iron (II) sulfate, while brighter colors are produced by alum. The appearance of this color shade is strongly influenced by the combination of chromophore and auxochrome groups which are also present in the molecular structure of each fixer.

TABLE III. COLORFASTNESS WITH VARIOUS COMPOSITIONS OF HYBRID NATURAL DYES AND FIXERS

\begin{tabular}{|c|c|c|c|}
\hline No. & $\begin{array}{l}\text { Material } \\
\text { Composition } \\
(\% \mathrm{v} / \mathrm{v})\end{array}$ & Fixer & Staining Scale (1-5) \\
\hline 1 & KKS (100) & $\begin{array}{l}\text { Iron (II) } \\
\text { sulfate }\end{array}$ & 3 (Fair) \\
\hline 2 & KKS (100) & Alum & $\begin{array}{l}2 \quad \text { Not good } \\
\text { enough) }\end{array}$ \\
\hline 3 & KKS (100) & Lime & $\begin{array}{l}2 \quad \text { Not good } \\
\text { enough) }\end{array}$ \\
\hline 4 & KKS/DL $(75 / 25)$ & $\begin{array}{l}\text { Iron (II) } \\
\text { sulfate }\end{array}$ & 3 (Fair) \\
\hline 5 & KKS/DL $(75 / 25)$ & Alum & $\begin{array}{l}2 \quad \text { (Not good } \\
\text { enough) }\end{array}$ \\
\hline 6 & KKS/DL $(75 / 25)$ & Lime & $\begin{array}{l}2 \quad \text { (Not good } \\
\text { enough) }\end{array}$ \\
\hline 7 & $\mathrm{KKS} / \mathrm{DL}(50 / 50)$ & $\begin{array}{l}\text { Iron (II) } \\
\text { sulfate }\end{array}$ & 3-4 (Good enough) \\
\hline 8 & KKS/DL (50/50) & Alum & 3 (Fair) \\
\hline 9 & KKS/DL (50/50) & Lime & 3 (Fair) \\
\hline 10 & KKS/DL $(25 / 75)$ & $\begin{array}{l}\text { Iron (II) } \\
\text { sulfate }\end{array}$ & $\begin{array}{l}2 \quad \text { (Not good } \\
\text { enough) }\end{array}$ \\
\hline 11 & KKS/DL $(25 / 75)$ & Alum & $\begin{array}{l}2 \quad \text { (Not good } \\
\text { enough) }\end{array}$ \\
\hline 12 & KKS/DL (25/75) & Lime & 3-4 (Good enough) \\
\hline 13 & DL (100) & $\begin{array}{l}\text { Iron (II) } \\
\text { sulfate }\end{array}$ & 3-4 (Good enough) \\
\hline 14 & DL (100) & Alum & 3-4 (Good enough) \\
\hline 15 & DL (100) & Lime & $\begin{array}{l}2-3 \quad \text { Not good } \\
\text { enough) }\end{array}$ \\
\hline
\end{tabular}




\section{CONCLUSION}

Exploration and standardization of natural dyeing as a substitute for synthetic dyes has been carried out. Hybrid dyeing is done by combining brazillin from brazilwood bark and tannins from lamtoro leaves extract. The dyeing results show the appearance of reddish, purple, brownish and blackish shades on the cotton fibers. The application of this hybrid dyeing has resulted in a color intensity in the range of $30.89 \%-89.36 \%$ with fastness reaching a scale of 3 (fair) to 3-4 (good enough).

\section{ACKNOWLEDGMENT}

The author would like to Universitas Negeri Surabaya for the financial support provided through the 2019 Higher Education Flagship Development Research Program.

\section{REFERENCES}

11 N. Kusumawati, S. Muslim, and A. Kistyanto, "Operational condition optimization on blacu fabric dyeing technology (case study: mordanting influence on napthol color quality and mechanical strength of blacu," Research Journal Pharmaceutical, Biological \& Chemical Sciences, vol. 7, pp. 672-682. 2016.

[2] N. Kusumawati, A. B. Santosa, M. M. Sianita, and S. Muslim, “ Extraction, characterization, and application of natural dyes from the fresh mangosteen (Garcinia mangostana L.) peel", International Journal on Advanced Science, Engineering, Information Technology, vol.7(3), pp. 878-884. 2017

[3] N. Kusumawati, T. Koestiari, and A. B. Santosa, "The influence of washing process using TRO on indigosol dyeing quality, leaching percentage, and mechanical strength of mori fabric", Research Journal Pharmaceutical, Biological \& Chemical Sciences, vol.6(6), pp.55-63. 2015 .

[4] A. Rosyida and A. Zulfiya, "Pewarnaan bahan tekstil dengan menggunakan ekstrak kayu nangka dan teknik pewarnaannya untuk mendapatkan hasil yang optimal”, Jurnal Rekayasa Proses, vol. 7(2), pp. 52-58. 2013.
[5] S. Saxena and A. S. M. Raja. Natural dyes: sources, chemistry, application and sustainability issues. In: Roadmap to Sustainable Textiles and Clothing. Singapore : Springer Singapore, 2014.

[6] R. Vettumperumal, S. Kalyanaraman, G. Tamil Selvan, and P. Mosae Selvakumar, "Fluorescence analysis of natural dyes from Plumeria rubra (red and white) flowers", Optik, Vol. 159, pp. 108-114. 2018.

[7] N. Kusumawati, A. B. Santosa, A. Wijiastuti, "Development of textile natural dyeing using hybrid dyes from mango leaves turmeric", Advanced in engineering research, vol. 171, pp. 50-55. 2018.

[8] K. Mohini, L. Tejashree, and N. Vijay, "Dataset on analysis of dyeing property of natural dye from Thespesia populnea bark on different fabrics", Data in Breaf, vol.16, pp. 401-410. 2018.

[9] N. B. Guesmi, N. L. Hamadi, and F. Sakli, "Dyeing properties and colour fastness of wool dyed with indicaxanthin natural dye", Ind. Crop. Prod. vol. 37, pp. 493-499. 2012.

[10] M. A. R. Bhuiyan, A. Islam, S. Islam, A. Hossain, and K. Nahar, "Improving dyeability and antibacterial activity of Lawsonia inermis L on jute fabrics by chitosan pretreatment', Text. Cloth. Sustain. Vol.3 (1), pp. 1-10. 2012.

[11] M.A. R. Bhuiyan , A. Islam , A. Ali, and M.N. Islam, "Color and chemical constitution of natural dye henna (Lawsonia inermis L) and its application in the coloration of textiles "Journal of Cleaner Production, vol. 167, pp. 14-22. 2017.

[12] A. Alamsyah, "Kerajinan Batik dan Pewarnaan Alami", Endogami: Jurnal Ilmiah Kajian Antropologi, vol. 1(2), pp. 136-148. 2018.

[13] S. W., R. Linda, and Mukarlina, "Pemanfaatan Tumbuhan Sebagai Bahan Pewarna Alami Oleh Suku Dayak Bidayuh Di Desa Kenaman Kecamatan Sekayam Kabupaten Sanggau”, Protobiont, vol. 6(3), pp. 303 - 309. 2017.

[14] S. Bahri, Jalaluddin, and Rosnita, "pembuatan zat warna alami dari kulit batang jamblang (Syzygium cumini) sebagai bahan dasar pewarna tekstil”, Jurnal Teknologi Kimia Unimal, vol.6(1), pp. 10-19. 2017.

[15] N. Kusumawati, L. Mufida, and R.A. Annisa, Pewarna alami untuk tekstil, Surabaya : Unesa University Press, 2018.

[16] R. Sari andSuhartati, "secang (Caesalpinia sappan L.) : tumbuhan herbal kaya antioksidan”, Info Teknis EBONI, vol. 13(1), pp. 57 - 67. 2016.

[17] N. T. Anggraini, "Pengaruh frekuensi celupan terhadap hasil jadi pewarnaan batik dengan daun lamtoro pada kain katun", Thesis of Bachelor Degree, Universitas Negeri Surabaya, 2014 